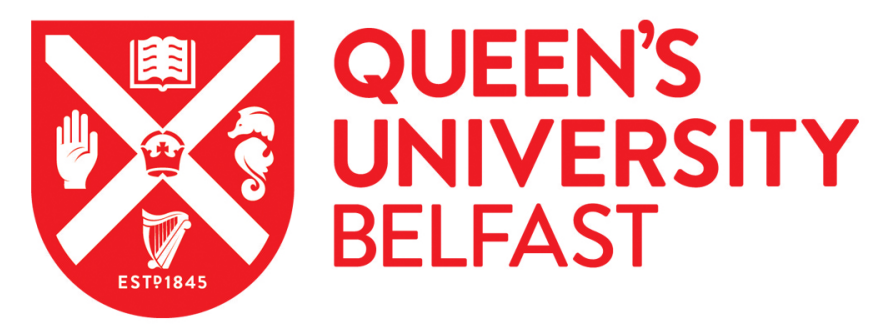

\title{
On Portraying Human Dignity
}

McCrudden, C. (2017). On Portraying Human Dignity. In A. Kemmerer, C. Möllers, \& D. Grimm (Eds.), Human Dignity in Context (Recht in Context). Nomos (Baden-Baden).

\section{Published in:}

Human Dignity in Context

\section{Document Version:}

Peer reviewed version

Queen's University Belfast - Research Portal:

Link to publication record in Queen's University Belfast Research Portal

\section{Publisher rights}

(C) 2017 Nomos Verlagsgesellschaft.

This work is made available online in accordance with the publisher's policies. Please refer to any applicable terms of use of the publisher.

\section{General rights}

Copyright for the publications made accessible via the Queen's University Belfast Research Portal is retained by the author(s) and / or other copyright owners and it is a condition of accessing these publications that users recognise and abide by the legal requirements associated with these rights.

\section{Take down policy}

The Research Portal is Queen's institutional repository that provides access to Queen's research output. Every effort has been made to ensure that content in the Research Portal does not infringe any person's rights, or applicable UK laws. If you discover content in the Research Portal that you believe breaches copyright or violates any law, please contact openaccess@qub.ac.uk. 
[Forthcoming in: Alexandra Kemmerer, Christoph Möllers, and Dieter Grimm (eds), Menschenrecht (Nomos (Baden-Baden), 2016) (Recht in Context)]

\title{
On Portraying Human Dignity
}

\author{
Christopher McCrudden*
}

\section{Introduction}

There is a well-known scene in The Simpsons, which is an American cartoon show for the over-16s, when Kirk and Luanne are playing Pictionary.! This involves players guessing the word or phrase as it is being 'drawn' by their partner. Kirk is seen drawing what looks to the viewer like a random set of squiggles on the board and saying to his partner, Luanne, somewhat testily: 'Ah, come on Luanne, you know what this is.' Luanne says: 'Kirk, I don't know what it is.' Kirk sighs and says: 'It could not be more simple, Luanne. You want me to show this to the cat, and have the cat tell you what it is? 'Cause the cat's going to get it.' After a lot of argument between the two of them, Kirk gives up in frustration at Luanne's inability to 'get' it, and says: 'It's dignity! Don't you even know dignity when you see it?'

But Luanne is dismissive of Kirk's efforts. He challenges her: 'Okay, genius,' he says to her, 'why don't you draw dignity.' She goes to the drawing board, and sketches something. Everyone gasps in recognition, but we, the viewers, can't see it because it's hidden from our sight. We're none the wiser, but we're supposed to be left with the idea that if only we were able to see the picture that Luanne had drawn, we too would gain an insight into dignity. Or, at least that is the initial idea we are supposed to take from the scene. But, of course, the joke is actually a lot deeper than that, as it nearly always is in The Simpsons: in fact, it's a critique of the idea that one picture is worth a thousand words.

So, from the ridiculous to the sublime. What I want to consider is whether Diego Velázquez (1599-1660) succeeded in doing in Las Meninas what Kirk in The Simpsons wasn't able to do, and whether Velázquez has indeed conveyed several aspects of the idea of human dignity in ways that do not just echo some aspects of contemporary philosophical and legal analysis, but transcend them, bringing into our understanding aspects of dignity, and the controversy surrounding it, that otherwise might be underestimated.

\footnotetext{
* An earlier version was presented at the Straus Institute, New York University Law School, where I was a Fellow in the academic year 2013-14. I am particularly grateful to Alexandra Kemmerer, Emily Kidd White, Aden Kumler and David Freedberg for commenting on an earlier version.

'The Simpsons, episode 6, season 8: 'A Milhouse Divided', first broadcast December I, 1996.
} 
The aims of this chapter

When I chose Las Meninas as the cover of a recent edited book of essays on human dignity, I was blissfully unaware of the extent to which the painting had been viewed by countless others in multiple settings. Las Meninas, painted in 1656, has intrigued pretty much everyone who has ever seen it. ${ }^{2}$ I know it did me when I first saw it in the Prado in Madrid in the early 1990s. In drawing on Las Meninas to make a broader point in philosophy, I am following in the illustrious, if controversial, ${ }^{3}$ steps of none other than Michel Foucault. ${ }^{4}$ Foucault has an extensive discussion of the painting in the first chapter of his 1966 book, ${ }^{5}$ but he uses the painting in a way that differs from my use. For Foucault, the painting usefully problematizes issues of representation through its use of mirrors and screens; for me, it provides insights into ways of thinking about human dignity. As we shall see, however, the approach that Foucault adopted, focusing on the complex perspectives embedded in the painting, and our position as spectators in the painting, are also important for my project.

My purpose in this article is partly, therefore, to engage in a retrospective justification of the use of the painting in the dignity context. At the time I included the painting on my book cover, I thought that making the connection between dignity and Las Meninas was an original idea; I should have known better, of course. Andrew Edgar had already linked the painting to the representation of dignity, in his 2003 article. ${ }^{6}$ Indeed, Edgar had already argued, as I shall here, that '[f]undamental questions about the very notion of dignity lie at the core of much of Velázquez's work, and indeed it may be suggested that they find their culmination in Las Meninas'.7 He also usefully documents how others have seen strong connections between the painting and conceptions of dignity. I want to continue that conversation. To help in this endeavor, I will draw on recent work by Avishai Margalit ${ }^{8}$ and

\footnotetext{
${ }^{2}$ The scholarly literature on Velázquez, and the paining is, of course, immense. For an introduction to the former, see SL Stratton-Pruitt, 'Introduction: A Brief History of the Literature on Velázquez' in SL Stratton-Pruitt, The Cambridge Companion to Velázquez (Cambridge, Cambridge University Press, 2002). For an introduction to the literature on the paining, see SL Stratton-Pruitt, 'Velázquez's Las Meninas: An Interpretive Primer' in SL Stratton-Pruitt, Velázquez's Las Meninas (Cambridge, Cambridge University Press, 2003).

${ }^{3}$ See Y Greslé, 'Foucault's Las Meninas and art-historical methods' (2006) 22 Journal of Literary Studies 211 .

${ }^{4}$ I am grateful to Robert Yelle, who first pointed this out to me.

${ }^{5}$ M Foucault, Les Mots et Les Choses (trans as The Order of Things).

${ }^{6}$ A Edgar, 'Velázquez and the representation of dignity' (2003) 6 Medicine, Health Care and Philosophy III.

7 ibid.

${ }^{8}$ A Margalit, 'Human dignity, between kitsch and deification' in C Cordner (ed), Philosophy, Ethics, and a Common Humanity: Essays in Honour of Raimond Gaita (London, Routledge, 20II).
} 
Hans Joas, 9 both of whom have presented their work as lectures associated with the two conferences of dignity at the Wissenschaftskolleg zu Berlin, from which this volume draws.

More broadly, I want to continue a conversation in the legal academy (I am, after all, a legal scholar) on how far resort to art forms such as literature and painting may help us understand problematic concepts in law and moral philosophy. 10 Iris Murdoch has famously claimed that great art 'is the most educational of all human activities and a place in which the nature of morality can be seen. Art gives a clear sense to many ideas which seem more puzzling when we meet them elsewhere.'II She continues: 'we may be able to learn more about the central area of morality if we examine what are essentially the same concepts more simply on display elsewhere.'12 This aspect of the article is, however, a secondary element, and one that I shall only hint at in addressing my primary concern.

[insert Figure I here: Velázquez's Las Meninas, https://www.museodelprado.es/en/thecollection/online-gallery/on-line-gallery/zoom/I/obra/the-family-of-felipe-iv-or-lasmeninas/oimg/0/]

Looking at Las Meninas

Let's turn to look at the painting itself. It's a complex painting. Here is one way of viewing what is going on, although this interpretation is contested. ${ }^{13}$ What we seem to see is a selfportrait of Velázquez, painting the king and queen of Spain, King Philip IV and his second wife Mariana of Austria, who are standing where we, the spectators, are placed. The king and queen are seen reflected in a mirror at the back of the room. Looking at the king and queen as they are being painted, and looking at us, the spectators, is a group composed from among the royal household - the extended 'family' of the royal couple; indeed, the painting was originally known by a title that reflected this 'family' element. ${ }^{14}$ The apparent centerpiece of this group is a young girl, the five-year-old Infanta, Doña Margaret Theresa,

\footnotetext{
${ }^{9}$ H Joas, Die Sakralität der Person. Eine neue Genealogie der Menschenrechte (Berlin, Suhrkamp, 2012), trans as The Sacredness of the Person: A New Genealogy of Human Rights (Washington DC, Georgetown University Press, 2013).

${ }^{10} \mathrm{I}$ am thinking, in particular, of the debate in the legal academy over the use of literary texts since JB White's The Legal Imagination: Studies in the Nature of Legal Thought and Expression (Boston, Little, Brown and Co., 1973), in which the use of literature is seen as a valuable means of illuminating law by stimulating critical thought.

"I Murdoch, The Sovereignty of Good (London, Ark Paperbacks, 1985) 87 f. I am grateful to Emily Kidd White for drawing this to my attention.

12 ibid 89.

13 On the variety of possible interpretations, see R Wicks, 'Using Artistic Masterpieces as Philosophical Examples: The Case of Las Meninas' (2010) 68 Journal of Aesthetics and Art Criticism 259.

${ }^{14}$ It was originally known as El Cuadro de la Familia, then as La Familia de Filipe IV.
} 
their daughter. She is with two of her ladies-in-waiting, or meninas, on either side of her. On the right of the painting is Doña Isabel de Velasco. On the left of the painting is Doña Maria Agustina Sariento, who is offering the Infanta something to drink, in a red cup on a silver tray. They form the main group. It looks like the Infanta is perhaps playing up, because the meninas look as if they are trying to surround her, dancing attendance on her, even perhaps trying to control her.

Outside this group, there is an additional collection of people. To the right of the painting as we look at it, there is what looks like a young boy, but whom we know is Nicolasito Pertusato, who is actually a dwarf. He is prodding what appears to be a sleeping dog, possibly playing with it, or trying to provoke it. Next to him, there is another dwarf; she is Mariabárbola. Behind the two dwarfs are two other people, one apparently dressed in religious garb, Doña Marcela de Ulloa, the Infanta's chaperone (or guardamujer). She is talking to an unidentified soldier or bodyguard. And last, there is a courtier at the back of the painting, standing in the doorway. He is Don José Nieto Velázquez, the queen's chamberlain. So, what is it about 'human dignity' that causes me to feel I should resort to choosing art to help our understanding, and why does Las Meninas help in this regard?

\section{Relating Las Meninas to dignity}

One of the current problems with 'dignity-talk', at least in some jurisdictions, is what has been termed 'dignity-fatigue', which I understand to mean that the current ubiquity of the concept is leading to its degradation. Dignity is now so commonplace that it ceases to have the power that it once had in pointing to important fundamentals. This degradation is important, not least because 'human dignity' has been identified as $a$, if not the, central principle on which human rights are based; if 'dignity' becomes degraded, then so too will human rights. Here, perhaps, is where other media can assist-in confronting the spectator directly, without the 'corrupting' effect of an overused word.

There are several further functions that Las Meninas might play initially in understanding the idea of dignity. One important debate in our current attempts to understand the concept concerns the history of the concept: there is an debate between those who see the use of human dignity in earlier times as having a significant degree of continuity of meaning with its use in later times, as opposed to those who see the history of 
dignity as one of significant discontinuities in meaning. ${ }^{15}$ Does dignity have a relatively similar meaning in different historical contexts? And what are the implications if it doesn't? In thinking further about this debate, we might look at Las Meninas as a historical artifact and think about what it tells us about the evolution of the meaning of dignity in the Spanish court of the 17th Century, in much the same way as Lynn Hunt and Joseph Slaughter attempt to do with the concept of 'human rights' by examining novels. 16

Second, we might look at Las Meninas not from the historical perspective but more broadly: as a way of articulating (representing?) something of universal significance that is true across space and time, helping us to understand how dignity is to be understood as a principle that transcends historical contingency. For example, a powerful understanding of dignity is that it expresses the idea that a person should be accorded respect due to their status, as opposed to the view that dignity involves the deeper issue of what it means to be human? Terms like 'equal moral worth', or in German 'Menschenwürde,' capture this idea. The problem in undertaking this second approach is that we may feel that in seeing the universal represented in the painting all we do is to find our current understanding; that all perspectives of dignity, perhaps, are necessarily contingent and context specific. (We might even think that this is true of all supposed universal principles: that we simply translate whatever is current into that principle.) Dignity (and this painting) is conceived to be an empty vessel into which each generation pours its own understandings.

I should say immediately that I do not think that Velázquez intended Las Meninas to represent 'Dignity', in the sense that those in the tradition of iconology that preceded him sought explicitly to 'represent' particular virtues. ${ }^{17}$ But I do partly engage here in what Suzanne Stratton-Pruitt has termed an 'emblematic reading' of the painting, by which she means a reading of a painting that sees it as 'representing' something additional to the subjects that form the ostensible basis of the painting. ${ }^{18}$ In my case, I want to explore the extent to which Las Meninas can usefully be seen as emblematic, even if unintentionally, of 'dignity'. But perhaps it is better to say that I adopt what Denis Donoghue has described as 'interpretation as exemplification', where 'someone analyses a work of art not for its own

\footnotetext{
${ }^{15}$ Contrast the approaches adopted by S Moyn, 'The Secret History of Constitutional Dignity' in C McCrudden (ed), Understanding Human Dignity (Oxford, Oxford University Press, 2013) and R Scott, 'Dignité/Dignidade: Organizing against Threats to Dignity in Societies after Slavery' in McCrudden, Understanding Human Dignity.

${ }^{16}$ L Hunt, Inventing Human Rights: A History (New York, WW Norton, 2008); JR Slaughter, Human Rights, Inc: The World Novel, Narrative Form, and International Law (New York, Fordham University Press, 2007).

${ }^{17}$ See, eg, Cesare Ripa Perugino, Iconologia (1618), in which Dignity is portrayed in the guise of a woman bearing [bearing up?] under a heavy load.

${ }^{18}$ Stratton-Pruitt, Velázquez' Las Meninas 126.
} 
sake but to offer it as an example, proof, or illustration of some argument he wants to make'. ${ }^{19}$ All this is by way of entering a caveat: this chapter is emphatically not an attempt at art history or art criticism, as those disciplines are traditionally conceived.

Dignity as rank and honor

How does the painting relate to dignity? To begin with, there is a very clear picture of one understanding of dignity captured in the form of the Infanta. If ever there was someone conscious of her dignity, in the sense of her honor and her rank, it is she. This is the sense in which EH Gombrich could write that the royals in Velázquez's paintings 'were men and women who insisted upon their dignity'. ${ }^{20}$ And those dancing attendance are also clearly conscious of the difference in rank, not only in focusing on the Infanta (the lady-in-waiting to her left is kneeling), but also (in the case of the second lady-in-waiting) in being careful to keep a close eye on the king and queen, seeming to check with them what she needs to do. The painting presents the different ranks in the royal household. ${ }^{21}$ So, we clearly have a strong representation of dignity in the sense of rank, honor, and social status. And we are quite able to understand this, and appreciate its advantages (after all, it resulted in Velázquez painting this scene, didn't it?), at the same time as worrying about the inequality and hierarchy on which it was based.22

The idea of dignity as honor remains highly important in some legal contexts, particularly in the law of countries influenced by Roman Law. ${ }^{23}$ That use is, however, a remnant. Some argue that the way we should understand the modern conception of dignity is to build on this idea of dignity as status, but to democratize it, introducing an egalitarian element into the equation. Jeremy Waldron suggests that modern democratic dignity accords to every person that which formerly only aristocrats were accorded. ${ }^{24}$ And this has,

\footnotetext{
${ }^{19} \mathrm{D}$ Donoghue, quoted by Stratton-Pruitt, Velázquez' Las Meninas 134.

${ }^{20} \mathrm{EH}$ Gombrich, The Story of Art, 5th edn (London, Phaidon, 1989) 320, quoted in Edgar, 'Velázquez and the representation of dignity' II 2 .

${ }^{21}$ Edgar, 'Velázquez and the representation of dignity' 119.

22 The advantages of hierarchy in producing great art are highlighted in G Katab, Human Dignity (Cambridge, Mass, Harvard University Press, 20I2).

${ }_{23}$ 'In a Roman context, dignitas very much meant rank or status. Individuals were endowed with different degrees of dignitas, and the delict inuria could be said to have at its core the disruption of this hierarchy; inuria was committed whenever the defendant willfully raised himself above, or brought the claimant below, the status granted to them by society.' E Descheemaeker, 'Solatium and Injury to Feelings: Roman Law, English Law and Modern Tort Theory' in E Descheemaeker and H Scott (eds), Inuria and the Common Law (Oxford, Hart Publishing, 2013) 94.

${ }^{24} \mathrm{~J}$ Waldron, Dignity, Rank, and Rights (M Dan-Cohen ed, Oxford, Oxford University Press, 20I2).
} 
indeed, some persuasive force. ${ }^{25}$ So, we can quite easily imagine (at least those of us fortunate enough to have daughters) how we might want the Infanta's self-confidence and poise to be something all little girls of her age develop. As a general proposition, however, Waldron's argument simply doesn't work. In particular, borrowing from Don Herzog and Michael Rosen's critiques of Waldron, 26 the Infanta's dignity depends on others not having the same status as she has. Indeed, not all of the many advantages possessed by her, and the aristocratic class of which she is a member, should be accorded to everyone. Generalizing or equalizing the privilege to everyone would hardly fit modern ideas of human dignity.

We can also test Waldron's understanding of dignity by turning back to Las Meninas, and considering the figure of Velázquez himself. One of the most striking features of this figure is the presence of a red cross on his tunic. This represents the Cross of St James of the Order of Santiago, and the consensus among art historians is that this must have been added later, since he only received the honor after the painting had been completed. ${ }^{27}$ To be made a knight of this Order required the consent of a commission established to enquire into the purity of the candidate's lineage. The aim of these enquiries was to prevent the appointment of anyone found to have even a taint of 'heresy' in their background, a broad concept that included having a trace of Jewish or Moorish blood; Velázquez's possible Jewish heritage, ${ }^{28}$ had to be waived aside. How can we generalize to everyone the anti-Semitism and hypocrisy on which this system of dignity depends? The honor bestowed depended on its being exclusive and exclusionary.

Dignity of art, and dignity of work

There is, however, an additional interpretation of the figure of Velázquez in the painting that gives a different meaning also to the inclusion of the Cross of the Order of Santiago on Velázquez's chest. To become a member of the Order, it was also necessary that a candidate establish that he was not contaminated by engagement with trade or commerce on either side of the family. Velázquez's plebeian origins, and his occupation as an artist engaged in the commerce of being paid to paint, were therefore important barriers to gaining membership. In this interpretation, the painting represents part of Velázquez's claim that he was worthy to be included in the Order because engaging in artistic production was

\footnotetext{
${ }^{25}$ Similar arguments have been made by KA Appiah, The Honor Code: How Moral Revolutions Happen (New York, WW Norton, 20II) 130.

${ }^{26}$ Don Herzog's critique is contained as a comment in Waldron, Dignity, Rank, and Rights 79. M Rosen's critique along similar lines is to be found at 79.

${ }^{27}$ S Alpers, 'Interpretation without Representation, or, the Viewing of Las Meninas' (1983) I Representations 3I, 4I fn 5 .

${ }^{28}$ Wicks, 'Using Artistic Masterpieces as Philosophical Examples' 272 fn 24.
} 
meritorious, and was worthy of praise and honor, an honor subsequently recognized by the award of the Order. Seen from this perspective, the painting is an attempt by Velázquez to assert 'the dignity of his art'. ${ }^{29}$

Was this also a way of asserting the 'dignity of work', that later 19th Century trade unionists and others loudly proclaimed? Some have seen this broader implication in the painting. Bryon Hamann's study of Las Meninas seeks to 'restore visibility to men and women who cannot be directly seen within the painting itself, 30 by focusing on the silver tray on which the red ceramic cup is placed, together with the deep red curtains hanging over the heads of the king and queen. Each of these, he argues, derived in one way or another from Spain's American colonies. For Hamann, applying a materialist postcultural interpretation, these objects 'can be read as reflections of the value-producing labor of men and women' in these colonies, and therefore as introducing into the painting a recognition of what would later be called 'the dignity of labor'. ${ }^{1}$

However, as Emily Umberger and Francesca Bavuso observe in their response to Hamann, there is no evidence that either Velázquez or his European audience was 'particularly conscious' of these implications. ${ }^{32}$ Indeed, rather than trying to hint at the dignity of labor of the sort that produced the objects included in the painting, Velázquez 'was distancing himself from lower-class artists and craftsmen'. ${ }^{33}$ For Alpers, the painting is a "claim for the nobility of painting as a liberal art and ... a personal claim for nobility on the part of Velázquez himself. In short, Las Meninas is now interpreted as a visual statement of the social rank desired by the painter'. ${ }^{34}$ After all, associating his work with that of the laboring classes would have further discouraged the award of the honor of membership of the Order.

The existence of such a strong distinction between labor and production, on the one hand, and artistic endeavor, on the other, does, however, point to a different conclusion regarding the 'dignity of labor'. By the late eighteenth century, as Umberger and Bavuso point out, the changes in economic thought regarding labor and production were beginning to be reflected in art, but not in the time of Velázquez." 'What we see in the seventeenth

\footnotetext{
${ }^{29} \mathrm{~J}$ Brown and C Garrido, Velázquez: The Technique of Genius (New Haven, Yale University Press, 1998) 27, quoted in Edgar, 'Velázquez and the representation of dignity' 120.

${ }^{30}$ B Hamann, 'The Mirrors of Las Meninas: Cochineal, Silver, and Clay' (2010) 92 The Art Bulletin 6, 29.

${ }^{31}$ ibid.

${ }^{32}$ E Umberger and F Bavuso, 'Reflections on Reflections' (2010) 92 The Art Bulletin 54, 57.

33 ibid 56.

${ }^{34}$ Alpers, 'Interpretation without Representation' 33.

35 ibid.
} 
century are ... steps in the development of such concerns.' In other words, our understanding of what constitutes 'dignity' changes over time and builds on what has gone before, spreading the net of empathy wider and wider. The logic of dignity seems to lead to it escaping the boundaries we seem to place on it. Velázquez's own oeuvre hints at this. An extraordinary, 1650 portrait in New York's Metropolitan Museum depicts Velázquez's Moorish slave, Juan de Pareja, who served as an assistant in his workshop, and whom he later freed. Here is someone who clearly possesses dignity, despite his origins and status, and his manual labor. Velázquez may have wanted to distinguish the dignity of the artist from productive labor in Las Meninas, but in his portrait of Juan de Pareja, this distinction is subtly undermined. 36

[insert Figure 2 here: Velázquez’s Juan de Pareja http://www.metmuseum.org/collection/thecollection-online/search/437869]

The King's two dignities

The ambiguity that we see comparing Velázquez's paintings is reflected also in Las Meninas itself, although in a different way. There is, in the painting itself, a certain degree of ambiguity about dignity. We obtain some inkling of this by thinking more about the portrayal of the king and queen. In this period, and indeed later, 'dignity' was often associated with the office that a person held. This understanding of 'dignity', as something associated with the status of office, goes back to Roman times. The king is in a particularly interesting position in this regard. The dignity of the king, qua king, had long been recognized. In England, for example, Elizabethan judges recognized the king as possessing a 'Body politic, which contains his royal Estate and Dignity'. ${ }^{37}$ But this gave rise to a problem: how should we regard the king otherwise?

To solve this problem, the King was recognized as having 'two bodies', the Body politic and the Body natural. For Ernst Kantorowicz, the fascinating contortions that this gave rise to provided endless interest, but for our purposes one in particular is pregnant with meaning for understanding the development of dignity. We see in the portraiture of the royals in the Spanish court of the 16th Century a similar understanding of the dual nature of kingship, both office and person at the same time. For Erasmus of Rotterdam, it was the king's 'inner virtues, not the symbols of power and authority' that 'made a truly good king'.

\footnotetext{
${ }^{36}$ Historically, too, there is a connection between the 19th Century emancipation movement, and the development of the idea of the dignity of labor.

${ }^{37}$ Quoted in EH Kantorowicz, The King's Two Bodies (Princeton, Princeton University Press, 1957) 9.
} 
The king's 'prestige, his greatness, his regal dignity must not be established and preserved by noisy displays of privileged rank but by wisdom, integrity, and right action'. ${ }^{38} \mathrm{We}$ begin to see, therefore, the development of the idea of 'dignity' as arising not from holding a particular office, but from possessing particular qualities.

Antorio Feros argues that the Spanish royals, at the time of Velázquez, 'sought to cultivate this Erasmian iconographic model of the ideal monarch, privileging a pictorial representation ... of the king as an individual who embodied the virtues of a good ruler ...'39 Velázquez depicted the royals as virtuous, paternalistic, and benevolent rulers'. 40 What better way to do this than to portray the king and queen, as in Las Meninas, as surrounded by his 'family', which for many years was regarded as a metaphor for the people as a whole? ${ }^{41}$ By emphasizing the king's Body natural, his true dignity as king arises from his individual virtues. It is a relatively small step from seeing dignity arising from particular human qualities to seeing dignity arising from the quality of being human, another way in which dignity seems able to escape its boundaries. We can see a hint, therefore, of the parallel understanding of dignity that had emerged earlier, one not based in the status of office, but based rather in one's position as a person. Kantorowicz credits Dante with the essence of the same idea in his description of 'Man' in the Inferno, and with it the idea of Dignity attaching to a person by virtue of being a 'Man', an understanding reflected also in Pico's famous oration, often seen as one of the earliest articulations of a humanistic understanding of dignity. ${ }^{42}$ In this context, dignity is understood as the inestimable value we regard human persons as having, simply in virtue of the basic human qualities they possess as humans.

\section{Dignified behavior}

We shall return to this point subsequently, but before doing so, we need to complicate things a little more, by introducing a further understanding of dignity as 'dignified behavior', especially in the face of trial and adversity. We say that a person acts with dignity, for example, when they don't collapse when someone close to them dies. Terms like fortitude, forbearance, acting with restraint in the face of adversity, are all associated with this idea.

\footnotetext{
${ }^{38}$ Quoted in A Feros, “'Sacred and Terrifying Gazes": Languages and Images of Power in Early Modern Spain' in Stratton-Pruitt, Cambridge Companion to Velázquez 83.

${ }^{39}$ ibid.

${ }^{40}$ ibid 86.

${ }^{41}$ JM Blythe, 'Family, Government, and the Medieval Aristotelians' (1989) 10 History of Political Thought 4.

${ }^{42}$ Kantorowicz, The King's Two Bodies 493.
} 
With that idea in mind, let's turn to another, for me perhaps the most noteworthy feature of Las Meninas. Apart from the Infanta, what is particularly striking about the scene presented to us is the inclusion of the two dwarfs. That the dwarfs are included in the family group at all is highly significant. Dwarfs had been included in numerous paintings prior to Velazquez, but 'they were almost never depicted as autonomous beings; rather they are shown as decorative elements situated at the fringes of the lives of others more important than themselves'. ${ }^{43}$ Velazquez, however, painted at least ten portraits of dwarfs, which transcend this tradition. Las Meninas is, apparently, one of the first examples in modern portraiture of servants being painted literally on the same level as the master. The dwarf to the left of the picture is probably achondroplastic, which accounts for her size and shape. But, significantly, she is portrayed as taller than the Infanta. Also, as Janet Ravenscroft points out, she 'is not actively serving the young princess, but rather stands and gazes confidently out at the viewer' (and, of course, at the King and Queen also). ${ }^{44}$

One of the attractive qualities of Velázquez's paintings is his willingness to paint some of the most excluded parts of human society. Let's turn first to another of Velázquez's dwarf paintings also now in the Prado, the 1645 portrait of the dwarf Sebastián de Morra, who was a jester at the court of Philip. Velázquez portrays his whole body, sitting on the ground, wearing a rich cloak but with his short legs pointing forward in an inelegant position reminiscent of a marionette. He looks directly at the viewer. His hands are motionless, but they appear to be tightly clenched. With this painting, we should also revisit Velázquez's painting of his slave, Juan de Pareja, who exudes a quiet confidence, an inner strength.

[insert Figure 3 here: Velázquez's The Buffoon Sebastián de Morra, https:/www.museodelprado.es/en/the-collection/online-gallery/on-line-gallery/obra/thebuffoon-sebastian-de-morra/]

One way of viewing these dwarfs and the slave is as examples of dignified behavior in the face of adversity: the noble slave, proud and unbowed despite his slavery; the suggestion in Sebastián de Morra's expression of a barely suppressed frustration at his physical condition and an implicit denunciation of the court's humiliating treatment of him

\footnotetext{
${ }^{43}$ BM Adelson, The Lives of Dwarfs: their journey from public curiosity towards social liberation (New Brunswick, NJ, Rutgers University Press, 2005) 146.

${ }^{44} \mathrm{~J}$ Ravenscroft, 'Invisible friends: Questioning the representation of the court dwarf in Hapsburg Spain' in W Ernst (ed), Histories of the Normal and the Abnormal: Social and Cultural Histories of Norms and Normativity (London, Routledge, 2006) 46.
} 
and other dwarfs. ${ }^{45}$ Or, we might see something deeper, of Velázquez's attempt to capture something in the human person that transcends their temporal status. So, JP Dominguez has written that Velázquez painted them 'with humanity' showing them to be 'as human as their masters'. He concludes: 'He respected their dignity as human beings and delineated their individual personalities. ${ }^{46}$ Why is his portrait of the slave so striking? Not because the slave was equal in status to Velázquez, he clearly isn't, but because the human in the slave is so clearly recognized and recognizable. We see the slave's humanity, in spite of his servitude; in spite of his inequality, in spite of his lowly position in the hierarchy. And so it is with Sebastián de Morra and the dwarfs in Las Meninas. But why?

\section{Dignity and autonomy}

One explanation may lie in the fact that several of those portrayed look out at us from the painting. As Edgar observes, Morra 'stares back at the spectator'. ${ }^{47} \mathrm{We}$ earlier used the word 'gaze' to describe what the subjects in Las Meninas are doing. The word 'gaze' is important here. Svetlana Alpers distinguishes between a gaze and a glance. The gaze, as is the case in this painting, 'signals from within the picture that the viewer outside the picture is seen and in turn it acknowledges the state of being seen'.48 Our eyes meet, and we are on the same level. The Morra painting, ' $\ldots$ in effect demands that the spectator interacts with Morra as an equal. That is to say that Morra is necessarily attributed the rights of a competent and equal participant in social interaction'. ${ }^{49}$ He exercises agency; he is an autonomous individual.

Velázquez's portrayal of the dwarfs is in marked contrast to other depictions. Those who have seen The Wolf of Wall Street ${ }^{50}$ will remember vividly the scene in which the traders, masters of the universe, New York gods we might say, are discussing the hiring of a dwarf to be used as a human dart, to be fitted with Velcro and thrown against a huge dart board. It is significant that in the film, the traders continually refer to the dwarf they will hire as 'it'. Not he, not she; but 'it'. A thing, not a person. Something to be instrumentalized in

\footnotetext{
${ }^{45}$ A point made by Edgar, 'Velázquez and the representation of dignity' I I7. See further Adelson, The Lives of Dwarfs 149 (discussing the views of others who made similar observations). The portrayal of dwarfs in Las Meninas is now a subject of interest in disability studies, see, for example, M Davidson, The Rage of Caliban: Missing Bodies in Modernist Aesthetics, available at: www.northumbria.ac.uk/static/5007/fadss/Lect_3_Rage_of_Caliban.pdf. ${ }^{46}$ JP Dominguez, 'El niño de Vallades [Francisco Lezcano]' (1989) 26 I Journal of the American Medical Association 496.

${ }^{47}$ Edgar, 'Velázquez and the representation of dignity' 118.

${ }^{48}$ Alpers, 'Interpretation without Representation' 32.

${ }^{49}$ Edgar, 'Velázquez and the representation of dignity' 1 I 8.

${ }^{50}$ Wolf of Wall Street, 2013, based on the autobiographical account by J Belfort of his own rise and fall, see The Wolf of Wall Street (New York, Bantam, 2007).
} 
the crudest way. And readers who know the jurisprudence on dignity, will know well that one of the most famous cases deals with dwarf-throwing and the compatibility of this activity with the idea of human dignity. ${ }^{51}$ Mr Manuel Wackenheim complained to the United Nations Human Rights Committee that, when France banned dwarf throwing, he was put out of a job which he regarded as rewarding, particularly given the difficulties he faced in getting other employment. France argued that the ban was in the interests of protecting human dignity. Wackenheim argued that putting him out of a job infringed his autonomy; indeed, some view this idea of autonomy as itself what dignity is about, and the ban on dwarf throwing as moralistic paternalism.

Sense and sensibility towards the human person

But France won in the Human Rights Committee, not Mr Wackenheim. Unlike Edgar, the Committee did not accept that Menschenwürde is equivalent to the exercise of autonomy and reason. An individualistic, autonomy-based understanding of dignity did not capture its meaning; instead, we find a relational understanding of dignity, where Mr Wackenheim's willingness to be thrown, his willingness to be humiliated, had to be seen as having adverse effects on others, notably other dwarfs. There is an additional problem with interpreting dignity as 'autonomy'. Edgar argues that the paintings of the slave, or the dwarfs, because they emphasize autonomy and reason, fall short of portraying the value of the human simply in virtue of their humanity, and that this is shown by the absence of equivalent dignity being accorded to those portrayed in two other paintings by Velázquez, the paintings of Calabazas and Francisco Lezcano. 52 In these paintings, two other court jesters are portrayed, both of them mentally disabled. In neither of these paintings does Edgar find the dignity that is present in the painting of Morra. Although all the subjects gaze back at us, the two court jesters do not interact with us in the way that the others do. For this reason, he argues, there is 'not yet dignity as Menschenwürde, for there is no clear identification of such grounding human capacities of autonomy and reason'. ${ }^{53}$

[insert Figures 4 and 5: Velázquez, the paintings El bufón Calabacillas, https://www.museodelprado.es/coleccion/galeria-on-line/galeria-on-line/obra/el-bufon/ and Francisco Lezcano, "El Niño de Vallecas", https://www.museodelprado.es/en/thecollection/online-gallery/on-line-gallery/obra/francisco-lezcano-the-boy-from-vallecas/]

\footnotetext{
${ }^{51}$ Wackenheim v France, Communication No 854/1999, U.N. Doc. CCPR/C/75/D/854/1 999 (2002). Similar decisions have resulted in several different jurisdictions, eg in Germany, see Beschluss des VG Neustadt vom 21. 05. 1992 - Aktz: 7 L 127I/92, available at: http://www.saarheim.de/Entscheidungen/VG\%20Neustadt\%20-\%207\%20L\%20I 27 I aus92.htm.

${ }^{52}$ Edgar, 'Velázquez and the representation of dignity' 120.

53 ibid.
} 
If the idea of dignity we get from the painting isn't satisfied by a status-based approach, or one based on the idea of the dignified person suffering in silence, or autonomy, what else is there? l've suggested earlier that a core meaning of dignity is the idea that the individual person has dignity simply by virtue of being human, and that this is an understanding of the human in relation to others. For me, what comes from the portraits of the dwarfs is the same deep impression that we get from the portrait of the slave, a sense of him as a person, not a thing, and the same goes for the representation of the dwarfs, and of the jesters.

One way of capturing this specialness is to think of the human as in some way 'sacred'. For Hans Joas, the connecting thread in the history of human rights is in this 'sacralization of the person'. ${ }^{44}$ The belief in human rights and universal human dignity is, he argues, 'the result of a specific process of sacralization-a process in which every single human being has increasingly, and with ever-increasing motivational and sensitizing effects, been viewed as sacred, and this understanding has been institutionalized in law'. Whilst acknowledging the importance of Lynn Hunt's work, he distinguishes her idea of the 'expansion of empathy' from his idea of the 'progressive sacralization of the person'. For Joas, the 'dimension of sacralization' seems 'more fundamental than that of empathy. People choose whether to 'allow their capacity for empathy ... to come into operation'; it needs something to get it going. ${ }^{55}$ Empathy depends, he suggests, on the sacralization of the person for its effectiveness in practice, because the sacralization of the person 'motivates us to show empathy; empathy alone does not engender the sacralization of the person, of all persons. ${ }^{56}$

Joas then asks: 'Why do people experience certain things as sacred? And how do we get to a point where each person becomes sacred ...?"57 The answers to these questions, he suggests, lie in 'a theory of the genesis of values, an investigation into value-constitutive experiences and especially those experiences that may give rise to an affective attachment to values rooted in moral universalism. ${ }^{58} \mathrm{He}$ portrays the genesis and development of human rights 'as a history of the relocating' of 'subjective certainty, the sense of self-evidence and

\footnotetext{
${ }^{54}$ Joas, The Sacredness of the Person 5: 'the history of human rights is a history ... of the sacralization of the person'.

55 ibid 59.

${ }^{56}$ ibid 60.

${ }^{57}$ ibid 153.

${ }^{58}$ ibid $153 \mathrm{f}$.
} 
affective intensity of the kind characteristic of the sacred'.59 This process 'straddles the sphere of practices, values, and institutions'. ${ }^{60}$

Joas demonstrates this by detailed studies of specific historical changes, considering how, in the case of torture, it was transformed from being widely practiced and acceptable before the 18th Century to being largely unacceptable by the mid-19th Century. The changes that occurred in the 18th Century involved, he argues, a 'profound cultural shift in which the human person became a sacred object', which meant the 'integration of thosesuch as criminals ... - who had not been self-evidently included within this concept' previously. ${ }^{61}$ So too, he sees 'the demand for the abolition of slavery' in the 19th Century as 'another radical movement for inclusion'.62 He describes the movement for abolitionism as a 'morally informed movement' that saw the world 'from the perspective of others and not just those with whom we are linked by established affective ties .... ${ }^{63}$ Armed with this insight, we can return, yet again, to Las Meninas. What is its relevance to Joas' argument? Martha Nussbaum has suggested that the added value that literature and, by extension, art bring to the philosophical, political, and legal controversy is not sense (meaning rationality) but sensibility, an orientation towards the human person.64 She doesn't call this dignity, but there is a strong resemblance. Velázquez, painting in 17th Century Spain, seems to provide an earlier, if limited, example of the phenomenon that Joas describes, but, in doing so, he also provides a portrait that continues to speak to us in these terms.

Does Art help or hinder?

We need to be careful however. Both Emmanuel Levinas and Avishai Margalit have warned, in different but related ways, of potential problems that can make the use of visual representations for the purpose of understanding dignity a parlous exercise. For Levinas, the problem is that the use of such representations threatens to weaken, if not destroy, the humanity that it aims to capture. ${ }^{65}$ Levinas grounds the phenomenon of the human (including human dignity) in the personal, transcendent, ethical demand of another human being. Being

\footnotetext{
59 ibid 173.

60 ibid 173.

${ }^{61}$ ibid 49.

${ }^{62}$ ibid 63. This is examined in detail in ch 3.

63 ibid 91 .

${ }^{64}$ M Nussbaum, "'Finely Aware and Richly Responsible”: Moral Attention and the Moral Task of Literature' (1985) 82 Journal of Philosophy 516.

${ }^{65}$ This account draws heavily from the excellent discussion by J Zimmermann, 'Levinas's Humanism of the Other' in J Zimmermann, Humanism and Religion: A Call for the Renewal of Western Culture (Oxford, Oxford University Press, 2012).
} 
human means having concern for others. Encountering the 'other' face-to-face becomes the most foundational structure of human reality. But art has a tendency to distort face-to-face relationships. Art, he argues, consists in substituting an image for the object it is portraying. Art's image making no longer maintains a living relationship to the concept portrayed but freezes it in the image. The image not only objectifies the 'other', but also ensnares the spectator. Images encourage spectators to think of themselves as mere objects among other objects. As a result, he suggests, art encourages passivity and thus diminishes our sense of responsibility. Art not only does not have the human quality of the living instant, it can also enchant with its beauty. Art's beauty lures us into a world without suffering and justice, again encouraging the evasion of responsibility. Art places its own representation between the person viewing the picture and reality, becoming a barrier to a real encounter. In a painting, the represented elements do not serve as symbols by which one gains access to a reality; rather, their presence bars the way to a living reality.

For Levinas, however, art is not necessarily irredeemable, but it requires the voice of the art critic to free the ethical from the freezing effect of the artistic method. Criticism integrates the inhuman work of the artist back into the human world, by re-attaching the artist and his work to its socio-political influences, to real history. But the art critic needs the help of the philosopher, for philosophy understands the larger and deeper sources of the emergence of art. Only ethical transcendence carried out by art critics, assisted by philosophy, prevents art from becoming mere images of reality or idolatrous vehicles of pleasure. Ethical transcendence restores our encounter with, and responsibility to, others, in whose proximity we can detect the trace of a just God.

We can leave to one side whether this understanding is convincing more generally, and focus on whether it captures what happens when we view Las Meninas. On the one hand, it is clear that we are drawn into the painting, and on one view at least we are encouraged to think of ourselves as sharing in the status of the King and Queen. But does this render the viewer passive, and dull our sense of responsibility? And is the top-down, elitist view that we need the art critic and philosopher to understand it correct? In these respects at least, Levinas fails to convince. Indeed, Velázquez seems to have gone out of his way to prevent us, the viewer, settling into the role of passive object, and encouraged us to explore our role. As Leo Steinberg has observed, there is a 'kind of reciprocity': 'Something we bring to the picture-the very effectiveness of our presence-ricochets from the picture, provokes an immediate response, a reflex of mutual fixation ...'66 The perspectival

\footnotetext{
${ }^{66}$ L Steinberg, 'Velázquez' Las Meninas' (198I) 19 October 45, 50.
} 
complexity of the painting means that we are constantly challenged to locate where we stand. ${ }^{67}$ Are we standing together with the King and Queen, thus appearing to be accorded their status and perspective?68 Or, rather, as careful geometric analysis of the painting has suggested, has the audience an eye level of about $4 \frac{1}{2}$ feet, which indicates we may be the same height as one of the dwarfs, with a very different perspective from that of the King and Queen? The effect, therefore, is to require us to think carefully about who we are, and what our perspective is (literally and figuratively). This does not support a Levinasian interpretation; rather the opposite.

\section{Dignity and kitsch}

For Margalit, there is a different, but equally unfortunate, tendency in the discussion of human dignity in the secular context: to conceive of the individual in highly sentimentalized terms, and it is on this aspect of portraying dignity through art that I want to focus now. Human rights activism is especially prone to the tendency towards this sentimentality, or kitsch. In order to promote the cause of the moment, we seek to construct a narrative of a pure victimhood (preferably in the shape of a child), one who has suffered something abominable, but is without anger or motives of revenge, and certainly defenseless, without deadly weapons with which to respond. Seeking an understanding of what it means to be human from art may encourage, I think, a particular tendency towards kitsch of the type that Margalit identifies. And when we combine art with human rights, this tendency is particularly on display; think of the powerful impact of photographic images in human rights campaigning.

Strategically, of course, sentimentality may have a critically important role to play in bringing about a degree of sensibility towards others, even a degree of empathy. But we shouldn't mistake the strategy and its effects for a foundational concept strong enough to ground human rights. Empathy, as Joas argues, must be based on something more grounded if it is to be anything other than ephemeral. The question is whether the concept of human dignity supplies that need. Is it a concept we can rely on to provide both sense and sensibility, but without losing the critical importance of actual people, and without descending into kitsch sentimentality?

Dignity and animals

\footnotetext{
${ }^{67}$ See the discussion in Wicks, 'Using Artistic Masterpieces as Philosophical Examples' 265-68.

${ }^{68}$ As Foucault, Les Mots et Les Choses 15, appeared to believe.
} 
Look at the dog in Las Meninas. Would the dog be included within the scope of dignity? Probably not. But why not? Something deeper must be going on. Note, first, that one of the dwarfs has his foot on the dog, and is possibly kicking it, demonstrating his mastery over the dog, an echo perhaps of the famous passage in the Book of Genesis, in which God gives Man mastery over all living things. ${ }^{69}$ Note also that unlike all the humans in the picture the dog has its eyes closed. As Foucault observed, the dog lying on the floor is 'the only element in the picture that is neither looking at anything nor moving, because it is not intended ... to be anything but an object to be seen' ${ }^{70}$

What is it that distinguishes the human person, someone with human dignity, from something else that doesn't? Some consider that differences in capacities and capabilities are what distinguish the human from the non-human, ${ }^{71}$ whilst others (I'm among them) think that this approach may create more problems than it solves. We consider the jesters human, do we not, despite their obviously limited capacities? So too, animals share some capacities with humans, whereas those humans in a permanent vegetative state have far fewer capacities. Why are animals not included within human dignity, and those permanently incapacitated included? For Margalit, the problem in discussions of dignity is the reverse of that identified by Levinas: a tendency to deify the human person, to turn the person into the creator of all things, the center of the universe, and representations may encourage this tendency. It is not merely coincidental that the same passage in Genesis in which Man is given mastery of the earth also refers to Man being made in the Image of God.

\section{Dignity and religion}

Here is where another important debate is central. How far does human dignity have religious and theological presuppositions embedded in it and, if so, is that is a problem?72 The idea of humans being made 'in the image of God' is the common Judeo-Christian way of capturing the idea that the individual is in some sense sacred, different from the rest of creation, and given mastery over it. The implications this has for the possibility of dialogue between those who share and those who do not share these presuppositions is extraordinarily important. How far can arguments based on the mystery of human personhood permit engagement with secular philosophers or lawyers? Is dignity viewed in

\footnotetext{
${ }^{69}$ Genesis, ch I, verse 28 (Authorized Version).

${ }^{70}$ Foucault, Les Mots et Les Choses 14.

${ }^{71}$ See, eg, C Tollefsen, 'The Dignity of Marriage' in McCrudden, Understanding Human Dignity.

${ }^{72}$ Contrast J Rivers, 'Justifying Freedom of Religion: Does Dignity Help?' in McCrudden, Understanding Human Dignity, with M Rosen, Dignity: Its History and Meaning (Cambridge, Mass, Harvard University Press, 2012).
} 
this way simply a conversation stopper? Even if there is an added value that theological reflection brings to dignity, does it have a valid political or legal role to play? We shall return to consider this in a moment.

The pluralism of meanings of dignity

Before doing so, however, we need to step back and draw breath. So far, we have touched on at least five understandings of dignity: dignity as hierarchy, dignity as equal status, dignity as respect, dignity as dignified behavior, and dignity as the equal moral worth of human persons. These understandings are likely to conflict in significant respects. The conflict between religious and secular understandings of human dignity is only one set of conflicts apparent. There are various, sometimes overlapping, conflicts between the five understandings discussed..$^{73}$ As Joas puts it, what if, as happens in practice, 'one person's subjective sense of self-evidence diverges from another's or collides with it'? 'How then do we deal with such disagreement when it comes to values?"74 For Joas, it is possible to reach agreement on new areas of common ground. The character of this process can best be termed, following Parsons, 'value generalization'. 75 Parsons defines this as 'the inclusion, under a single legitimizing value-pattern, of components which are not only diverse and differentiated from each other, but many of which have, historically, claimed some sort of an "absolutistic" monopoly of moral legitimacy'.76 For Joas, Parsons's concept has two particularly important elements that distinguish it from other similar approaches: 'a dynamic process of mutual modification' and 'attention to the deeper layers of value systems and religions'. ${ }^{77}$ Religious values and understandings have a role to play in the conversation, but not as a conversation-stopper.

We have seen that there are significant disputes between those who see human dignity as having particular core substantive meanings (and l've talked about the different varieties of these substantive meanings), and between those who consider dignity to have religious underpinnings and those who do not (and l've asked whether a reconciliation between these viewpoints can take place). Importantly, there is a debate among theologians and others as to how far how far religious traditions should be open to the world, how far secular thinking can inform, even change, religious understandings of dignity, or how far the

\footnotetext{
${ }^{73}$ See further the introductory chapter 'In Pursuit of Human Dignity: An Introduction to Current Debates' by C McCrudden in McCrudden, Understanding Human Dignity.

${ }^{74}$ Joas, The Sacredness of the Person 173.

75 ibid 174.

76 ibid 179.

${ }^{77}$ ibid 181 .
} 
relationship should always flow from religion to society, and never the other way. Joas encourages us to consider that understanding may best come from openness on all sides to the other.

Conclusion: an unfinished project and the open door

With that in mind, let's return to Las Meninas one last time and observe two further aspects of the painting that we haven't mentioned so far. We should pay some attention to the painting that Velázquez is pictured beside, paintbrush in hand. This is clearly unfinished. Carlos Fuentes, in an interesting aside, considers the implications of this. 'Does it not', he asks, 'raise the possibility that everything in the world-this paining, but also this history, this narrative-is unfinished? And that, more specifically, we are unfinished ourselves, men and women who cannot be declared "complete," enclosed within boundaries of finitude and certainty ...'78

Let's now look at the chamberlain at the back of the room, in front of the open doorway. Without the doorway, drawing our gaze to the light, it would be an intensely closed, even claustrophobic, scene. There is only one other source of light from the window at the right of the painting, throwing light onto the Infanta. Because of its geometric position, the viewer is placed opposite this open doorway, looking through it to the light beyond. ${ }^{79}$ The significance of the open doorway is greater, however, because of the figure of the Chamberlain. We aren't sure, are we, whether he is coming or going? But in any event, what is important is that the openness of the doorway shows us that there is an outside, a world beyond, and the light of that world is available, if we just draw aside the curtain, as the Chamberlain has done. There is a relatively clear symbolic importance that we can discern, with the open doorway and the light beyond symbolizing 'genuine enlightenment beyond the social order'. ${ }^{80}$ As Robert Wicks suggests, 'only the painting's audience is in the position to see through the open, brightly illuminated doorway, beyond the painting's worldly realm and conceivably into the realm of the divine'. He continues that the message conveyed is that 'only be "standing outside of oneself"-in this case, only be standing outside of the painting —is the path to enlightenment discernable'. 81

\footnotetext{
${ }^{78}$ C Fuentes, The Buried Mirror: Reflections on Spain and the New World (Boston, Houghton Mifflin, 1992) 182.

${ }^{79}$ Wicks, 'Using Artistic Masterpieces as Philosophical Examples' 265.

${ }^{80}$ ibid 268.

${ }^{81}$ ibid 269.
} 
Combine the two elements: the unfinished canvas, and the open door leading to the light. From what I have suggested thus far, Las Meninas serves (literally) as a canvas on which the varieties of current debates about dignity can be illustrated and played with. It also has a 'distancing' function, helping as to not only to depict and play with current debates, but also to break disciplinary boundaries current in the conduct of these debates. ${ }^{82}$ Leaving the religious symbolism to one side, the open door in Las Meninas can serve to symbolize another strand of thinking about dignity, one that has come to the fore relatively recently. This views dignity as having utility primarily as a functionally useful device, rather than necessarily one with a particular substantive meaning. Some consider that the concept of human dignity may be useful primarily for allowing a dialogue to continue between those who fundamentally disagree about what it is to be human. ${ }^{83}$

What the Chamberlain is doing, perhaps, is inviting us to join an unfinished conversation in which others outside the room are engaged. On this reading, what Las Meninas provides, ultimately, is an experience which encourages us to 'share the ethical framework' of other people, as Anil Gomes suggests great art may do. ${ }^{84}$ In doing so, it seems a near perfect medium for better understanding the current dilemmas and debates over dignity; for in experiencing the painting we are pointed to the importance of what Murdoch called 'unselfing', 'the capacity to go beyond the personal prejudices arising from my own ego'. ${ }^{85}$ It inculcates a capacity for standing in another person's shoes, a capacity that is at the core of reflexivity, the 'perception of other as individual'. 86 It is not unique in doing this, but it is nevertheless important, particularly when words that provide the language for expressing that perception begin to lose their power to move us, as threatens to be the case with 'dignity'.

\footnotetext{
${ }^{82}$ See A Kemmerer, 'Dignified Disciplinarity: Towards a Transdisciplinary Understanding of Human Dignity' in McCrudden, Understanding Human Dignity.

${ }^{83}$ See, eg, R Siegel, 'Dignity and the Duty to Protect Unborn Life' in McCrudden, Understanding Human Dignity and P Carozza, 'Human Rights, Human Dignity, and Human Experience' in McCrudden, Understanding Human Dignity.

${ }^{84}$ A Gomes, 'Iris Murdoch on Art, Ethics, and Attention' (2013) 53 British Journal of Aesthetics 32I.

85 ibid 334.

${ }^{86}$ C Sedmak, 'Human Dignity, Interiority, and Poverty' in McCrudden, Understanding Human Dignity 562.
} 